\title{
FURTHER COMPARATIVE STUDIES OF SODIUM METHOHEXITAL ${ }^{1}$
}

\author{
Gordon M. Wyant, F.F.A.R.C.S., and James S. BARR, M.B., B.CH.
}

SODIUM METHOHEXITAL (Lilly 25398) has been the subject of a number of studies to evaluate its suitability for clinical anaesthesia (1-5). The drug is an oxybarbiturate, a fact which distinguishes it from all other commercially available ultra-short-acting barbiturates, with the exception of hexobarbital. Its chemistry and pharmacology have been described in a previous report (4).

In an earlier comparative study with sodium thiopental (4), each drug was used on a series of healthy women undergoing. D \& C. Either barbiturate was used for induction and maintenance of anaesthesia, oxygen only being administered by mask. On the basis of that study we came to the conclusion that methohexital, compared with thiopental, combined shorter action with greater potency. The relative potency of thiopental to methohexital was found to be $1: 1.54$ with a total sleep time ratio of 1:0.7. It was also found that induction with methohexital was slower which might lead to overdose until sufficient experience in the use of this drug has been gained. Apnoea following induction was less frequent with methohexital but was more prolonged when it did occur. While it was easy to maintain smooth anaesthesia by the intermittent administration of 2.5 per cent thiopental, the very short action and abrupt end point of methohexital made this mode of administration less practical. Induction with a 1 per cent methohexital solution followed by an 0.2 per cent intravenous drip was found more suitable! Untoward manifestations during anaesthesia such as hiccough were not particularly disturbing with methohexital and the incidence of undesirable emergence and recovery phenomena was no higher than with thiopental. After conclusion of anaesthesia, patients were more alert and less disorientated after methohexital. Neither methohexital nor sodium thiopental afforded consistently satisfactory relaxation for bimanual pelvic examination.

Having obtained these results it seemed advisable to carry out a further con= parative study which might approximate more closely the actual clinical use of both drugs. Thiopentahor methohexital was to be used for induction and thereafter in intermittent doses for supplementation of nitrous oxide anaesthesia, if and when required. This is a more desirable way of using barbiturates in anaesthesia; therefore, it would be interesting to know how methohexital compares with thiopental when used in this fashion. In order to eliminate any possible prejudices because of our previous studies and their findings, a blind study was decided upon.

${ }^{1}$ From the Department of Anaesthesia, University of Saskatchewan College of Medicine and University Hospital, Saskatoon.

Supplies of Methohexital were made available through the courtesy of Eli Lilly and Company Limited, Indianapolis, Ind. 


\section{MEthon}

As in the previous investigation, this series too was restricted to minor gynaecological procedures, using only patients in physical status 1,2 , and 5. Thiopental was used in a 2.5 per cent solution and methohexital in 1 per cent concentration. Fresh solutions of either drug were prepared in specially provided $50 \mathrm{ml}$. multidose ampoules whenever the previous solution was used up. Since solutions of methohexital arê colourless whereas thiopental has a yellowish tint, $1 \mathrm{ml}$. (6 mg.) of phenolsulfonphthalein was added to each $50 \mathrm{ml}$. of solution. Thus both solutions were coloured uniformly red and they were coded immediately after preparation. The administrator was not aware at the time of anaesthesia what agent he was using. Because of the different concentration of each agent, the amount administered was recorded initially in millilitres and later was translated into milligrams after the identity of the drugs had been revealed.

All patients were premedicated with meperidine and scopolamine intramuscuJarly, usually $50 \mathrm{mg}$. and $0.4 \mathrm{mg}$. respectively.

Immediately upon induction of anaesthesia, nitrous oxide $8 \mathrm{~L}$. and oxygen $2 \mathrm{~L}$. were administered by mask in a semi-closed system and thereafter supplemental doses of the same agent as had been used for induction were administered when needed to maintain adequate depth of anaesthesia.

In all, 111 patients were studied, of whom 56 received thiopental and 55 methohexital.

\section{Discussion of Results}

Age (Table I). The oldest and the youngest patients in both groups are listed as well as the mean ages. Although the extremes of ages were very close, there was a significant difference between the means, the average patient receiving thiopental being almost four years older than the one in the methohexital group. This is surprising since the patients were selected at random. It is unlikely, however, that this difference greatly influences the results of the study.

Height and weight (Table II). As far as the mean height and weight are concerned, there was no difference between the two groups under study.

Time from premedication to induction (Table III). There was no difference between the mean in the two groups. In all previous studies this was the most variable to standardize. In the present study premedication certainly did not influence the validity of the results.

TABLE I

AGE

\begin{tabular}{lcccccc}
\hline & $\begin{array}{c}\text { Oldest } \\
\text { (yrs.) }\end{array}$ & $\begin{array}{c}\text { Youngest } \\
\text { (yrs.) }\end{array}$ & \multicolumn{2}{c}{ Mean } & & \\
& (yrs.) & (mo.) & S.D. & \\
\hline Thiopental & 62 & 20 & 35 & 7 & 7.09 & $2.023^{*}$ \\
Methohexital & 61 & 18 & 31 & 11 & 10.66 & \\
\hline
\end{tabular}

*Significant $(P<.05)$ 
TABLE II

HEIGHT AND WEIGHT

\begin{tabular}{|c|c|c|c|c|c|c|}
\hline & $\begin{array}{l}\text { Mean height } \\
\text { (ins.) }\end{array}$ & S.D. & .. & $\begin{array}{l}\text { Mean weight } \\
\text { (lb.) }\end{array}$ & S.D. & \\
\hline Thiopental & 63.5 & 2.5 & \multirow{2}{*}{-1.089} & 130.8 & 26.8 & \multirow{2}{*}{0.049} \\
\hline Methohexital & 64 & 2.3 & & 130.5 & 24.3 & \\
\hline
\end{tabular}

TABLE III

Time from Premedicatioñ to Induction

\begin{tabular}{lccccccc}
\hline & \multicolumn{2}{c}{ Longest } & \multicolumn{2}{c}{ Shortest } & \multicolumn{2}{c}{ Mean } \\
& $($ hr. $)$ & (min.) & (min.) & (hr.) & (min.) & S.D. & \\
\hline Thiopental & 3 & 46 & 13.5 & 1 & 39 & 40.9 & 1.100 \\
Methohexital & 3 & 6 & 27 & 1 & 31 & 32.24 & \\
\hline
\end{tabular}

TABLE HV

DuRATION

\begin{tabular}{lccccc}
\hline & $\begin{array}{c}\text { Longest } \\
\text { (min.) }\end{array}$ & $\begin{array}{c}\text { Shortest } \\
(\mathrm{min})\end{array}$ & $\begin{array}{c}\text { Mean } \\
(\text { min.) }\end{array}$ & S.D. & $t$ \\
\hline Anaesthesia & 35 & 6 & 17.6 & 5.8 & -0.587 \\
$\quad$ Thiopental & 49 & 8 & 18.4 & 7.3 & \\
$\quad \begin{array}{l}\text { Methohexital } \\
\text { Operation } \\
\text { Thiopental }\end{array}$ & 28 & 5 & 12.1 & 5.0 & -0.127 \\
$\quad$ Methohexital & 38 & 5 & 12.3 & 6.6 & \\
\hline
\end{tabular}

Duration of anaesthesia and operation (Table IV). Again, there was no difference in the two groups and thus the results for the two drugs are not influenced by these factors.

Amount of drug used (Table V). The well-established fact that methohexital is a more potent drug milligram for milligram than thiopental has once again been corroborated. Both for induction and maintenance and as far as the total dose is concerned, 21\% times the amount of thiopental in milligrams was required than with methohexital. Since thiopental was given as a $2^{\frac{1}{2}}$ per cent solution and methohexital as a 1 per cent solution, the amount of anaesthetic in millilitres administered was identical. This result is at variance with our previous findings in which the ratio of thiopental to methohexital was 1:1.54. This apparent discrepancy can be explained by the fact that in the previous study each drug was used for the entire maintenance of anaesthesia whereas in the present study the burden of maintening anaesthesia was placed upon nitrous oxide and the intravenous barbiturate was used only for supplementation of nitrous oxide. The ratio of $2 \frac{1}{2}: 1$ is closer to that suggested by other authors who have used methohexital in a similar manner $(1,2)$. 
TABLE V

Amount of Drug Used

\begin{tabular}{lccccc}
\hline & $\begin{array}{c}\text { Maximum } \\
(\mathrm{mg} .)\end{array}$ & $\begin{array}{c}\text { Minimum } \\
(\mathrm{mg} .)\end{array}$ & $\begin{array}{c}\text { Mean } \\
(\mathrm{mg} .)\end{array}$ & \multicolumn{1}{c}{ S.D. } & \\
\hline $\begin{array}{l}\text { Induction } \\
\text { Thiopental }\end{array}$ & 250 & 100 & 133.3 & 26.3 & $19.726^{* *}$ \\
$\begin{array}{l}\text { Methohexital } \\
\quad\end{array}$ & 120 & 50 & 54.2 & 14.2 & \\
$\begin{array}{l}\text { Maintenance } \\
\text { Thiopental }\end{array}$ & 375 & - & 161.8 & 94.8 & $7.081^{* *}$ \\
$\quad$ Methohexital & 200 & + & 65.4 & 37.2 & \\
$\begin{array}{l}\text { Totals } \\
\text { Thiopental }\end{array}$ & 550 & 125 & 295.1 & 95.3 & $12.764^{* *}$ \\
$\quad$ Methohexital & 250 & 50 & 119.6 & 38.4 & \\
\hline
\end{tabular}

**Highly significant $(P<.01)$

Induction time (Table VI) was defined as the time from completion of the injection of the drug until surgical anaesthesia was reached. The fact that there is no significant difference between the two drugs is once again at variance with our previous findings. We had stressed before that methohexital, being a much more potent drug, must be injected more slowly than is customary for thiopental. Since this was a blind study, thiopental had to be administered at the same slow rate as is mandatory for methohexital. It is obvious, therefore, that if thiopental is used in the same cautious fashion which is essential for methohexital, induction with thiopental is no faster than with the new agent. In other words, the previous findings were due to the fact that liberty is taken with thiopental because of greater experience with this drug.

TABLE VI

INDUCTION TIME

\begin{tabular}{lcccccc}
\hline & $\begin{array}{c}\text { Longest } \\
(\mathrm{min.})\end{array}$ & $\begin{array}{c}\text { Shoc. } \\
(\mathrm{sec})\end{array}$ & $\begin{array}{c}\text { Mean } \\
(\mathrm{sec} .)\end{array}$ & S.D. & \\
\hline Thiopental & 2 & & 10 & $39.9^{\circ}$ & 22.8 & \\
Methohexital & 4 & 30 & 15 & 38.6 & 35.6 & 0.223 \\
\hline
\end{tabular}

Total sleep time (Table VII) was defined as the time from start of injection until the patient obeyed the simple verbal command of opening the eyes. There was a significant difference between the mean total sleep time, thiopental being the longer acting agent of the two. This confirmed our previous findings that methohexital is a shorter-acting agent and this finding also applies under the changed experimental conditions of the present study.

Waking time (Table VIII). Both the waking time from the last supplemental injection of the intravenous barbiturate and that from the end of inhalation anaesthesia are listed. The end point here again was obedience to simple verbal 
command. There was a highly significant difference between thiopental and methohexital, the mean waking time in both instances being much shorter following the administration of methohexital.

Time from wake-up to orientation (Table IX) was the time from obeying simple verbal command to the point when the patient was fully orientated as to place and time. Here again, the effect of methohexital proved less protracted in that patients were orientated sooner than after the administration of thiopental.

TABLE VII

Total Sleep Time

\begin{tabular}{lccccc}
\hline \hline & $\begin{array}{c}\text { Longest } \\
\text { (min.) }\end{array}$ & $\begin{array}{c}\text { Shortest } \\
(\mathrm{min} .)\end{array}$ & $\begin{array}{c}\text { Mean } \\
(\mathrm{min})\end{array}$ & S.D. & \\
\hline Thiopental & 59 & 7 & 25.3 & 10.9 & $2.335^{*}$ \\
Methohexital & 52 & 10 & 21.1 & 7.7 & \\
\hline
\end{tabular}

*Significant $(P<.05)$

TABLE VIII

WAKING TIME

\begin{tabular}{|c|c|c|c|c|c|}
\hline & $\begin{array}{r}\text { Longest } \\
\text { (min.) }\end{array}$ & $\begin{array}{c}\text { Shortest } \\
\text { (min.) }\end{array}$ & $\begin{array}{l}\text { Mean } \\
\text { (minin.) }\end{array}$ & S.D. & \\
\hline \multicolumn{6}{|l|}{ From last injection } \\
\hline Thiopental & 50 & 4 & 15 & 9.4 & \multirow{2}{*}{$3.653^{* *}$} \\
\hline Methohexital & 33 & 3 & 10.3 & 5.7 & \\
\hline \multicolumn{6}{|l|}{$\begin{array}{l}\text { From end of } \\
\text { inhalation } \\
\text { anaesthesia }\end{array}$} \\
\hline Thiopental & 46 & 1 & 7.7 & 9.7 & \multirow{2}{*}{$3.803^{* *}$} \\
\hline Methohexital & 9 & $\frac{1}{2}$ & 2.7 & 1.8 & \\
\hline
\end{tabular}

TABLE IX

TIME FROM WAKE-UP TO ORIENTATION

\begin{tabular}{|c|c|c|c|c|c|c|}
\hline & $\begin{array}{c}\text { Longest } \\
\text { (min.) }\end{array}$ & $\begin{array}{l}\text { Shortest } \\
\text { (sec.) }\end{array}$ & $\begin{array}{r}\text { M } \\
\text { (min.) }\end{array}$ & (sec.) & S.D. & \\
\hline Thiopental & 13 & 0 & 2 & 14.4 & 151.6 & \multirow{2}{*}{$2.069^{*}$} \\
\hline Methohexital & 5 & 0 & 1 & 26.2 & 85.1 & \\
\hline
\end{tabular}

*Significant $(P<.05)$

Apnoea (Table X). Whereas in our previous study the incidence of apnoea had been greater with thiopental than with methohexital, the mean duration being no different, in the present investigation no difference existed between the two drugs as far as both incidence and mean duration were concerned. Whereas it had been found that, if apnoea did occur with methohexital, it was much more prolonged than after thiopental, this was not found to be so in the present study. 
TABLE X

APNOEA

\begin{tabular}{|c|c|c|c|c|c|c|c|c|c|}
\hline & \multirow[b]{2}{*}{ Incidence } & \multirow[b]{2}{*}{ S.D } & & \multicolumn{6}{|c|}{ Mean Duration. } \\
\hline & & & & Apnoeic ases & S.D. & $t$ & All cases & S.D. & \\
\hline Thiopental & $8(14.3 \%)$ & .05 & \multirow{2}{*}{$1: 636$} & $43 \mathrm{sec}$. & 23.8 & \multirow{2}{*}{0.438} & 6.1 & 17.4 & \multirow{2}{*}{1.595} \\
\hline Methohexital & $3(5.4 \%)$ & .03 & & $377^{3} \mathrm{sec}$ & 7.6 & & 2 & 8.5 & \\
\hline
\end{tabular}

This was no doubt again due to the fact that thiopental was injected in a slower and more cautious manner than is customary since the identity of the drug was unknown at the time of administration.

Side-effects (Table XI). The only side-effects of note during anaesthesia were movements during maintenance. The high incidence of these movements was due to the fact that their occurrence was the only indication that additional supplements of the intravenous anaesthetic were required. The large majority of these movements were in the category of very slight or slight and as such were not even noticed by the surgeon. These and also moderate movements could be easily controlled by a further injection of anaesthetic. No severe movements which would include withdrawal of the pelvis during manipulation were seen. As one might expect most of the movements occurred at the stage of operation when stimulation was maximal, namely, during preparation of the lower abdomen and vagina with cold water, examination under anaesthesia, and dilatation of the cervical canal. It is, of course, at these stages of greater stimulation that the inadequate depth of anaesthesia becomes most obvious.

TABLE XI

SIDE-EFFECTS

A. TOTAL INCIDENCE

\begin{tabular}{|c|c|c|c|c|c|c|}
\hline & \multicolumn{2}{|c|}{ Cough } & \multicolumn{2}{|c|}{ Hiccough } & \multicolumn{2}{|c|}{ Movements } \\
\hline & Induction & Maintenance & Induction & Maintenance & Induction & Maintenance \\
\hline Thiopental & 0 & 0 & 0 & 0 & 0 & $42(75 \%)$ \\
\hline
\end{tabular}

B. SEVERITY OF MOVEMENT

\begin{tabular}{lcccc}
\hline & Very slight & Slight & Moderate & Severe \\
\hline Thiopental & 27 & 10 & 5 & 0 \\
Methohexital & 30 & 10 & 6 & 0 \\
\hline
\end{tabular}

c. STAGE OF PROCEDURE AT WHICH MOVEMENTS OCCURRED

\begin{tabular}{lccccccc}
\hline \hline & $\begin{array}{c}\text { Lithotomy } \\
\text { position }\end{array}$ & $\begin{array}{c}\text { Vaginal } \\
\text { Prepara- Catheteri- } \\
\text { tion }\end{array}$ & $\begin{array}{c}\text { Examina- } \\
\text { tion under } \\
\text { zationathesia }\end{array}$ & $\begin{array}{c}\text { Dilatation } \\
\text { of cervical } \\
\text { canal }\end{array}$ & $\begin{array}{c}\text { Curettage } \\
\text { antimulation }\end{array}$ \\
\hline $\begin{array}{l}\text { Thiopental } \\
\text { Methohexital }\end{array}$ & 3 & 19 & 2 & 18 & 9 & 0 & 5 \\
\hline
\end{tabular}


In comparing thiopental and methohexital one is struck by the similarity of the two agents as far as side-effects are concerned. None of these occurred during induction and even as far as the severity of the movements or the stage of procedure at which they occurred is concerned the incidence is very similar. One would conclude from this that there is no essential difference between the two drugs when they are used under the particular conditions of this study.

Recovery period (Table XII). Untoward manifestations during the recovery period were few with either drug. The incidence of nausea and emesis during the first 24 hours was slightly greater with thiopental than with methohexital, but in no case was the nausea prolonged. Only once was it severe enough to require the administration of perphenazine.

TABLE XII

ReCoveriy Period

\begin{tabular}{lccc}
\hline \hline & $\begin{array}{c}\text { Nausea and } \\
\text { emesis }\end{array}$ & Nausea & Headache \\
\hline $\begin{array}{l}\text { Thiopental } \\
\text { Methohexital }\end{array}$ & 5 & 1 & 1 \\
\hline
\end{tabular}

\section{SumMary ANd CoNClusions}

One of the most interesting features which has emerged from this study is the apparent discrepancy between our previous study and this one. In the previous study, the identity of each drug was known and was used both for induction and maintenance of anaesthesia. The present study was a blind one and each drug was given for induction of anaesthesia and then during maintenance only if nitrous oxide and oxygen alone were insufficient. These discrepancies emphasize a very basic fact of clinical and of experimental comparisons, namely that when conclusions are drawn as to the comparative properties of two or more agents, it must be clearly stated that the conclusions apply only to the experimental conditions under which the results were obtained. In other words, comparable values are not absolute entities but must be related to circumstances and to the basic experimental assumptions.

The comparison of means has certain limitations which must also be appreciated. In the original study, for instance, following the induction with a barbiturate it was always necessary to give at least one maintenance dose of the barbiturate, whereas in the present study nitrous oxide-oxygen maintenance alone was adequate in four of the thiopental cases and in two of the methohexital cases. Also the cases that remained adequately anaesthetized on nitrous oxide-oxygen alone were by no means always the shortest cases, nor had they received necessarily more than an average amount of barbiturate for induction. Indeed, the two longest cases induced with thiopental and maintained on nitrous oxide and oxygen without further supplement lasted 17 and $19 \mathrm{~min}$. respectively and had received only $125 \mathrm{mg}$. of thiopental for induction.

Nor is there a clear relation between the wake-up time and the total dose of barbiturate administered. For instance, the longest wake-up time after completion 
of inhalation anaesthesia supplemented by methohexital was 9 min. and this patient had received a total of $110 \mathrm{mg}$. of the drug for induction and maintenance; this is very close to the mean total dose. The shortest wake-up time was $30 \mathrm{sec}$. and this patient also had received $110 \mathrm{mg}$. of the same drug. The longest wake-up time after nitrous oxide supplemented by thiopental was 46 min. following administration of $375 \mathrm{mg}$. The patient who had been given the largest total dose of thiopental, $550 \mathrm{mg}$., awoke within $4 \mathrm{~min}$. of the end of inhalation anaesthesia, the mean being almost double that time. This at first glance seems odd until it has been calculated that the first patient received $19.5 \mathrm{mg}$. of thiopental per square meter body surface area per minute of anaesthesia and the second only $14 \mathrm{mg}$. This and many more or less tangible factors such as degree of apprehension or sedation, metabolic rate, effect of premedication, age, obesity, effect of nitrous oxide, etc., must be taken into account in relating dose to sleep time so that a mere comparison affords only limited information.

If any conclusion can be drawn from such a comparative study as the one here presented, it is this. If thiopental $2 \frac{1}{2}$ per cent or methohexital 1 per cent is used for induction of anaesthesia and for supplementation of nitrous oxide-oxygen anaesthesia for a standard operative procedure, and if both drugs are injected at the same rate, the degree of anaesthesia obtained and its quality are on the average quite similar, except that awakening following methohexital is quicker, and orientation is faster and more complete than with thiopental. These may be significant factors in out-patient practice and where good recovery room facilities are not available.

\section{ACKNOWLEDGMENT}

The authors acknowledge with thanks the assistance of Messrs. N. Purkin and D. Palko, who in their capacity as student interns, assisted with the study.

Professor N. Shklov of the Department of Mathematics did the statistical calculations.

\section{RÉSUMÉ}

Nous avons comparé, par la méthode à l'aveugle, du thiopental à 2/1/2 pour cent et du methohexital $\mathbb{1}$ pour cent chez 111 femmes en santé qui avaient à subir des opérations gynécologiques mineures. Pour le maintien de l'anesthésie, nous avons employé du protoxide d'azote et de l'oxygène que nous complétions à l'occasion, lorsque nécessaire, avec de petites quantités du barbiturique employé pour l'induction.

Après l'analyse des résultats, il nous semble que, lorsque nous employons ces agents de la façon décrite, il existe peù de différence dans les résultats si ce n'est que, avec le methohexital, le réveil est plus précoce et les malades redeviennent plus tôt complètement lucides.

Ces résultats ne confirment pas dans tous les détails ceux que nous avions obtenus au cours d'études comparatives antérieures de ces deux médicaments, ce que nous attribuons à la technique d'anesthésie différente employée au cours des 
deux études. Il est donc important de se mettré dans l'esprit que, lorsque nous faisons des études comparées de médicaments, les résultats ne se superposent pas nécessairement dans toutes les circonstances cliniques.

\section{REFERENCES}

1. Stoelting, V. K. The Use of a New Intravenous Oxygen Barbiturate 25398 for Intravenous Anesthesia (A Preliminary Report). Anesth. \& Analg. 36: 49-51 (May/June, 1957).

2. Redish, C. H.; Vore, R. E.; Chernish, S. M.; \& Gruber, C. M., Jr. A Comparison of Thiopental Sodium and Methohexital Sodium in Oral Surgery Patients. Oral Surg., Oral Med., \& Oral Path. 11 (6): 603-616 (June, 1958).

3. Weyl, R., UnAL, B., \& AlPER, Y. Clinical Evaluation of a New Ultrashort-Acting Oxygen Barbiturate for Intravenous Anesthesia. Surg., Gynec. \& Obst. 107: 588-592 (Nov., 1958).

4. Wyant, G. M., \& Chang, C. A. Sodium Methohexital: A Clinical Study. Canad. Anaesth. Soc. J. 6 (1) : 40-50 (Jan., 1959).

5. Friedman, E. Methohexital Anesthesia in Electrocerebral Therapy. Dis. Nerv. Syst. (Monograph Suppl.) 20 (5) : 121-124 (May, 1959). 